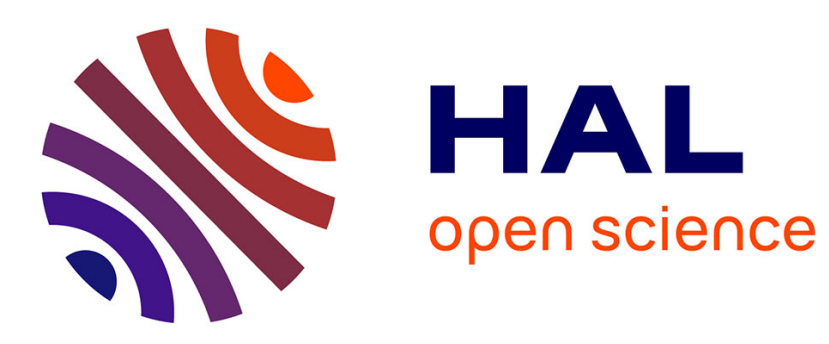

\title{
Fungi reduce preference and performance of insect herbivores on challenged plants
}

Pilar Fernandez-Conradi, Herve Jactel, Cécile Robin, Ayco J. M. Tack, Bastien Castagneyrol

\section{To cite this version:}

Pilar Fernandez-Conradi, Herve Jactel, Cécile Robin, Ayco J. M. Tack, Bastien Castagneyrol. Fungi reduce preference and performance of insect herbivores on challenged plants. Ecology, 2018, 99 (2), pp.300-311. 10.1002/ecy.2044 . hal-02622124

HAL Id: hal-02622124

https: / hal.inrae.fr/hal-02622124

Submitted on 26 May 2020

HAL is a multi-disciplinary open access archive for the deposit and dissemination of scientific research documents, whether they are published or not. The documents may come from teaching and research institutions in France or abroad, or from public or private research centers.
L'archive ouverte pluridisciplinaire HAL, est destinée au dépôt et à la diffusion de documents scientifiques de niveau recherche, publiés ou non, émanant des établissements d'enseignement et de recherche français ou étrangers, des laboratoires publics ou privés. 
Article Type: Articles

Running head: Fungus-plant-insect interactions

\title{
Fungi reduce preference and performance of insect herbivores on
}

\section{challenged plants}

\author{
Authors: Pilar Fernandez-Conradi ${ }^{*}{ }^{*}$, Hervé Jactel ${ }^{1}$, Cécile Robin ${ }^{1}$, Ayco J. M. Tack ${ }^{2}$, and \\ Bastien Castagneyrol $^{1}$
}

\author{
Affiliations: ${ }^{1}$ Biogeco, INRA, Univ. Bordeaux, F-33610, Cestas \\ ${ }^{2}$ Department of Ecology, Environment and Plant Sciences, Stockholm \\ University, SE-106 91 Stockholm, Sweden
}

Corresponding author*: INRA - UMR BIOGECO, 69 route d'Arcachon, 33612 Cestas

Cedex, France; Tel: +33(0)5 571227 37; Fax: +33(0)5 571228 81; E-mail address: pilar.fernandezconradi@gmail.com

\begin{abstract}
Although insect herbivores and fungal pathogens frequently share the same individual host plant, we lack general insights in how fungal infection affects insect preference and performance. We addressed this question in a meta-analysis of 1,113 case studies gathered from 101 primary papers that compared preference or performance of insect herbivores on control vs. fungus challenged plants. Generally, insects preferred, and performed better on, not challenged plants, regardless of experimental conditions. Insect response to fungus This article has been accepted for publication and undergone full peer review but has not been through the copyediting, typesetting, pagination and proofreading process, which may lead to differences between this version and the Version of Record. Please cite this article as doi: 10.1002/ecy.2044

This article is protected by copyright. All rights reserved.


infection significantly differed according to fungus lifestyle, insect feeding guild and the spatial scale of the interaction (local/distant). Insect performance was reduced on plants challenged by biotrophic pathogens or endophytes but not by necrotrophic pathogens. For both chewing and piercing-sucking insects, performance was reduced on challenged plants when interactions occurred locally but not distantly. In plants challenged by biotrophic pathogens, both preference and performance of herbivores were negatively impacted, whereas infection by necrotrophic pathogens reduced herbivore preference more than performance and endophyte infection reduced only herbivore performance. Our study demonstrates that fungi are may be important but hitherto overlooked drivers of plantherbivore interactions, suggesting both direct and plant-mediated effects of fungi on insect's behavior and development.

Key-words: biotrophic pathogens, endophytes, meta-analysis, necrotrophic pathogens, plant defense, plant-mediated indirect interactions, tripartite interactions

\section{Introduction}

Plant-associated fungi and herbivorous insects often co-occur on the same host plant. While most of the attention so far focused on their independent and additive effects on plant fitness (Hauser et al. 2013), direct and plant mediated effects of fungi on herbivorous insects are less well understood. Plant-associated fungi may modify plant functional traits and quality, and thus indirectly affect herbivorous insects (Friesen et al. 2011). Fungal infection can either increase (e.g., by releasing soluble sugars, Cardoza et al. 2003a) or decrease (e.g., through reduced nitrogen content, Hatcher et al. 1994a) the quantity and within-plant distribution of nutrients, thus affecting the performance of insects (Tinney et al. 1998, Cardoza et al. 2003a). 
Fungal infection can thus be detrimental (Hatcher et al. 1994a, Kruess 2002), beneficial (Friedli and Bacher 2001, Cardoza et al. 2002, 2003a) or neutral (Kok et al. 1996, Saikkonen et al. 2001) to herbivores. However, we still lack a quantitative estimate of the overall effect of fungal infection on insect preference and performance on challenged plants. Moreover, how these tripartite interactions depend on the feeding guild of the insect, lifestyle of the fungus and the spatial scale of the interaction remains to be comprehensively explored (Hatcher 1995, Stout et al. 2006, Tack and Dicke 2013).

The way by which fungi obtain resources from their living host plants may have profound consequences for insect herbivores. Among the five main functional groups of plantassociated fungi (mycorrhizae, epiphytes, endophytes, biotrophic pathogens and necrotrophic pathogens, Porras-Alfaro and Bayman 2011), mycorrhizae is the group that received the greatest attention with respect to its effect on herbivores. Koricheva et al. (2009) showed that the impact of mycorrhizal-infected plants on insect performance depends on herbivore feeding specialization. Mycorrhizal infection generally increase the performance of monoand oligophagous chewers and decrease the performance of polyphagous chewers. For sucking insects, mycorrhizal infection positively affects phloem feeders but has a negative impact on the performance of mesophyll feeders. Although they also received substantial interest over the past decades, the direct and indirect effects of plant infection by pathogenic fungi and endophytes on insect herbivores are far less well understood (Hatcher 1995, Stout et al. 2006, Raman et al. 2012, Tack and Dicke 2013). Our study focuses on biotrophic and necrotrophic pathogens and endophytes. Biotrophic pathogens develop and extract their nutrients from living plant tissues (Delaye et al. 2013, García-Guzmán and Heil 2014) while necrotrophic pathogens secrete enzymes and toxins that degrade and kill the host cells and then live and feed on the dead plant tissue (Spoel et al. 2007, Delaye et al. 2013, GarcíaGuzmán and Heil 2014). Both biotrophic and necrotrophic pathogens may produce molecules 
that are deterrent or toxic to herbivores, but are also frequently consumed by the herbivore while feeding on the host plant. Endophytes correspond to another lifestyle and are defined as 'microorganisms that live at least during a part of their life cycle inside living plant tissue without causing visible disease symptoms' (Partida-Martínez and Heil 2011). Although their status along the continuum between parasitism and mutualism is evolutionarily and ecologically unstable (Arnold 2007, Delaye et al. 2013), some endophytes are known to strongly influence the outcome of plant-herbivore interactions (Clay 1996, Kuldau and Bacon 2008, Saikkonen et al. 2010). Although endophyte-free plants do not exist (Arnold 2017, Partida-Martínez and Heil 2011, Peñuelas and Terradas 2014), the presence of particular endophyte species can have important consequences on plant functioning. Given the differences in the way that biotrophic pathogens, necrotrophic pathogens and endophytic fungi exploit plants, we predict that the direction and magnitude of fungal infection effects on insect herbivores depends on the fungus lifestyle.

Plants evolved common molecular mechanisms against aggression from both herbivores and fungal pathogens. Yet, not all mechanisms are elicited by, nor are effective against all aggressors. For instance, while the salicylic acid pathway is usually induced by and efficient against biotrophic pathogens and sucking herbivores, necrotrophic pathogens and chewing herbivores principally activate and respond to the jasmonic acid pathway (Spoel et al. 2007, Ali and Agrawal 2012, Thaler et al. 2012, Al-Naemi and Hatcher 2013). Given these specificities, we predict that the response of herbivores to plant infection by fungi will depend interactively on fungus lifestyle and herbivore feeding guild, with stronger negative effects of necrotrophic fungi on chewing than on sap feeding insects, but conversely more negative effects of biotrophic fungi on sap feeding insects. Mouttet et al. (2013) found partial support for this hypothesis. They showed a reciprocal negative effect of the sap-feeding whitefly Bemisia tabaci and the biotrophic pathogen Oidium neolycopersici in tomato plants, 
which is consistent with JA-SA crosstalk, but an asymmetrical positive effect of the leaf miner Tuta absoluta on tomato powdery mildew, which is inconsistent with JA-SA crosstalk.

Herbivores have often been reported to discriminate between "not challenged" (non-infected by a specific endophyte or pathogen) and "challenged" (by a specific endophyte or pathogen) plants, and thus exhibit preference. A likely reason is that fungal infection modifies the visual (Rizvi et al. 2015) or chemical cues (Rostás et al. 2015) that herbivores use to locate and select their host. However, there is no consensus about the consequences of such changes on herbivore behaviour: fungus challenged plants may be more (Johnson et al. 2003, Cardoza et al. 2003b, Jallow et al. 2008), less (Kruess 2002, Laine 2004, Menjivar et al. 2012) or as attractive as not challenged plants (Jallow et al. 2004, Spafford Jacob et al. 2007). Although it is generally assumed that insect preference matches insect performance (Gripenberg et al. 2010), fungal infection may break down the preference-performance relationship by modifying only herbivore preference or performance, or, alternatively, affect preference and performance in opposite directions (for example, the fungus may increase insect preference but decrease insect performance). For instance, Kruess (2002) showed an increase in the preference and performance of the leaf beetle Cassida rubiginosa on creeping thistle Cirsium arvense challenged by the necrotrophic fungus Phoma destructiva. By contrast, Jalow et al. (2004) found reduced performance of the polyphagous moth Helicoverpa armigera on endophyte challenged tomato plants but no significant differences in foliage consumed on inoculated $v s$. control plants in choice tests. Given these discrepancies among studies, a general overview of patterns and mechanisms is needed.

This article is protected by copyright. All rights reserved. 
At a within-plant scale, herbivores can discriminate between not challenged and challenged organs from the same host plant, and even between not challenged and challenged tissue of the same organ (e.g., the same leaf, Simon and Hilker 2003). But not all herbivores may be able to discriminate and avoid challenged organs or tissues. Notably, when the fungus and insect share the same plant organ, the effect of the fungus on the insect herbivore may be direct (through production of supplementary nutrients or toxins), indirect (i.e., fungal-induced changes in the host plant) or both. However, when a herbivorous insect feeds on not challenged organs of a fungal challenged plant, the effect of the fungus on insect performance is mainly indirect and mediated by changes in the host plant. As the impact of fungal infection on plant quality (direct and indirect) and fungal biomass may decrease with increasing distance from the site of infection, the effect of fungal infection on herbivore performance may then depend on the spatial scale of fungus-insect interactions (Simon and Hilker 2003, Tack and Dicke 2013, Mouttet et al. 2013). We thus hypothesize that the effect of fungal infection on herbivorous insects is stronger for local (i.e., when feeding on the same plant organ) than for distant (i.e., when feeding on the same plant) interactions.

Studies have tested how herbivore preference and/or performance are affect by fungal infection under both laboratory / greenhouse conditions (Friedli and Bacher 2001, Cardoza et al. 2003a) and in field experiments (Hatcher et al. 1994b, Kluth et al. 2001, Tack et al. 2012). Yet, field conditions are often more variable and the impact of fungal infection on the insect herbivore may therefore be obscured by confounding factors such as climatic conditions (e.g., water availability, Bultman and Bell 2003, Miranda et al. 2011) or local species pools of insects and fungi. We therefore hypothesize that the impact of fungal infection on insect herbivores is easier to detect, and has a stronger effect, under more controlled experimental conditions, i.e., in laboratory or greenhouse experiments. 
The main objectives of the present study were thus (1) to provide a quantitative estimate of the overall effect of fungal infection on the preference and performance of insect herbivores and (2) to explore the sources of variation in the magnitude of the fungus effect, by testing how insect feeding guild, fungus lifestyle, spatial scale of the interaction and experimental conditions impact on fungus-herbivore interactions. Detailed hypotheses and predictions are listed in Table 1.

\section{Materials and methods}

\section{Data collection}

We searched the published literature reporting fungal effects on herbivorous insects sharing the same host plant. A first set of studies was initially identified from Tack and Dicke's review (2013) on plant-pathogen-herbivore interactions, which was used to define keywords to be searched in the Web of Science (ISI) electronic bibliographic database. We applied combinations of relevant terms such as: "(Plant or tree) and (insect) and (preference or performance or choice) and (fung* or oomyc*) not bacteri* not virus not *mycorrh*”. We retained only articles, book chapters, reviews, theses, dissertations and abstracts published in English. To further limit the search to relevant papers, we filtered outputs to retain only those matching with the following research areas: plant sciences, environmental sciences, ecology, pathology, agriculture, zoology, forestry, chemistry, physiology, behavioral sciences, microbiology, entomology, biochemistry, molecular biology, parasitology and mycology.

The search was limited to the period 1950 - 2015. Our initial search yielded 1092 papers (the number of papers retained at each stage is reported in the PRISMA flow diagram, Appendix S1: Fig. S1). To complete our dataset, we surveyed the cited references in the articles retained and in the main reviews about plant-fungus-arthropod interactions (Rostas et al. 2003, Stout

This article is protected by copyright. All rights reserved. 
et al. 2006, Tack and Dicke 2013) and additionally screened the articles that cited these three review papers.

To be retained in the meta-analysis, studies had to meet the following criteria: (i) report insect preference for, or performance on, plants infected by the studied fungus (hereafter referred to as challenged plants) vs plants non infected by this specific fungus (hereafter referred to as not challenged plants), (ii) report taxonomic information about plant, insect and fungus, at least at the genus level and (iii) provide a measure of the mean and variability (i.e., variance, standard error or standard deviation) and the sample size in either the text, figures, tables or appendices. When needed, data were extracted from figures following digitalization using the open office extension Ooodigitizer version 1.2.1 and ImageJ. We finally retained 1,113 study cases from 101 primary papers (see also Appendix S1). List of corresponding references are available in Appendix S2.

\section{Moderators}

For each study case, we extracted the following moderators (explanatory variables): plant, insect and fungus species identity (at least at the genus level); fungus lifestyle (biotrophic pathogen, necrotrophic pathogen, or endophyte); insect feeding guild (chewing, piercingsucking, phloem feeding and sucking, cell-content sucking, sap-feeding, stem-boring, rootboring, pollen-feeding, bud-feeding and seed-feeding); experimental conditions (field and greenhouse or laboratory study); spatial scale of the interaction (local, when insects targeted organs challenged by the fungus, distant when insects targeted organs not challenged by the fungus, and missing data, $N A$, when organ infection was not explicitly indicated in primary papers); type of insect response (abundance, acceptance, attraction, body size, resource consumption, density, development rate, development time, digestibility, egg hatching, emergence, fecundity, generation length, growth, longevity, mortality, oviposition, 
oviposition deterrence, population growth, population size, pupation, reproduction, survival, weight). We eventually grouped insect responses into two categories: preference and performance. In some cases, the distinction between preference and performance was not straightforward. We decided to code corresponding cases as missing data (NA) to avoid spurious classification.

In addition to moderators, each study case was attributed a single identifier (Case ID) and assigned to one original paper (Study ID) and one study system (System ID). A Study ID corresponded to a single published paper retained in our analysis. A System ID was the combination of plant, fungus and insect species. Within a paper, each combination of plant, fungus and insect species was thus assigned to a specific study system (System ID). Within each Study ID, we considered as a Case ID any response variable measured for each pair of challenged and control plants. In most studies, more than one insect response variable was measured for the same system. Although variables from the same study were not strictly independent (e.g., insect weight and survival), we used all variables to avoid possible bias due to a priori exclusion of some variables or losing valuable information. Nonindependence among case studies was accounted for in the analyses using two independent and complementary approaches (see below, Statistical Analyses).

\section{Statistical analyses}

For each study case, we calculated an effect size using the Hedges' $d$ metric and its variance (Hedges 1981) as estimated with the 'metafor' package 1.9-8 version in R 3.2.3 (Viechtbauer 2010, R Core Team 2015). Refer to Appendix S3 for details of effect size calculation. First, we estimated the grand mean effect size using the complete data set. Second, we selected subsets of data for which there were enough observations for each level of moderators to enable testing their effects (Table 1). For instance, we excluded case studies on root-feeding 
$(k=78)$, seed feeding $(k=2)$, stem-boring $(k=32)$, pollen-feeding $(k=5)$ and bud-feeding insects $(k=4)$, and thereby only retained case studies on defoliators (chewing and mining insects) and piercing-sucking insects (including phloem feeders and suckers, cell-content suckers and sap-feeders).

To avoid confounding factors, moderators were tested using a hierarchical approach (Castagneyrol and Jactel 2012, Ferreira et al. 2015). Because results from field and laboratory/greenhouse studies may yield different results, we first tested the effect of experimental setting on effect sizes. Further analyses were restricted to laboratory/greenhouse studies for which it was possible to address the hierarchical effect of additional moderators (Appendix S1: Table S1).

In laboratory/greenhouse experiments, case studies were not evenly distributed among moderators (Appendix S1: Table S1). For instance, there were no case studies addressing the effect of plant infection by biotrophic pathogens on the preference of piercing-sucking insects. To avoid confounding the effects of fungus lifestyle and the type of insect response, we therefore used two independent models. We first tested how the effect size of fungal infection on insect performance was affected by fungus lifestyle (necrotrophic vs. biotrophic pathogen vs. endophytic fungi), insect feeding guild (chewers vs. piercing-sucking) and spatial scale of interaction (local vs. distant). Next, we compared the impact of fungal infection on insect preference vs. performance retaining only case studies where fungi and chewing insects interacted at the local scale, while accounting for fungus lifestyle (Appendix S1: Table S1).

This article is protected by copyright. All rights reserved. 
For both models, all two- and three-ways interactions were included in the full model. We applied model simplification by sequentially removing non-significant interactions, starting with highest order interactions. For model comparison, parameters were estimated using Maximum Likelihood. Parameters of the final model were estimated using Restricted Maximum Likelihood (REML).

Most primary studies provided more than one single study case. Multiple outcomes from the same study are correlated, which is likely to increase the variance of model parameter estimates (Koricheva et al. 2013). We accounted for non-independence among effect sizes by conducting multi-level error meta-analyses, using two moderators as random factors. In particular, different measurements of insects (e.g., survival, body mass, number of eggs) were frequently taken in the same study for the same combination of plant, fungus and insect species. Because measurements taken from the same model species were likely correlated, we used System ID (i.e., the combination of plant, fungus and insect species corresponding to each effect size) as a random factor. We used Case ID nested within Study ID as an additional random factor to account for correlation among multiple case studies within the same primary study.

To ensure that our results were robust and unbiased by non-independence among effect sizes, we additionally conducted a sensitivity analysis. We randomly selected one study case per primary study, system and moderator level and re-ran models (those selected by simplification procedures). This procedure was repeated 1000 times. We compared parameter estimates from the complete dataset to the distribution of 1000 estimates obtained from random subsets of case studies.

This article is protected by copyright. All rights reserved. 
We finally used four different approaches to verify that our results were not affected by publication bias (Koricheva et al. 2013): (1) inspection of funnel plots, (2) cumulative metaanalysis, (3) calculation of fail-safe number and (4) exploration of the relationship between effect-sizes and journal impact factor (Murtaugh 2002).

All analyses were conducted in $R$ (R Core Team 2015). Model parameters were estimated using the 'rma.mv' function from the 'metafor' package (Viechtbauer 2010). Post-hoc comparisons were done using the 'linearHypothesis' function from the 'car' package (Fox and Weisberg 2011).

\section{Results}

We identified a total of 1,113 case studies $(k)$ obtained from 101 original (primary) papers that quantified the effects of plant infection by fungi on insect preference and/or performance. This included 63 different plant species ( $84 \%$ being herbaceous), 65 fungal species and 99 insect species for a total of 205 different plant-fungus-insect combinations (i.e., 205 study systems).

The grand mean effect size $[ \pm 95 \% \mathrm{CI}]$ calculated with the full data set $(k=1113)$ was significantly negative and equaled $-0.42 \pm$ CI $[-0.64 ;-0.20]$, indicating that, generally, insects avoid and perform worse on challenged plants than on control, not challenged plants (H1 in Table 1).

Studies performed in the field or under laboratory experimental conditions provided qualitatively similar results $(k=137$, mean $=-0.36 \pm[-0.69 ;-0.02]$ and $k=976$, mean $=-0.44 \pm$ [-0.68; -0.21], respectively; H2 in Table 2), but effect sizes were notably of higher magnitude and less variable in laboratory studies than in field studies.

This article is protected by copyright. All rights reserved. 
Studies on chewing and piercing-sucking insects in laboratory studies represented $75 \%$ of the case studies $(k=839)$. For these insects, the grand mean effect sizes were consistently negative and significantly different from zero, even when only including case studies using laboratory and greenhouse conditions $(-0.38 \pm[-0.63 ;-0.12])$. In the analysis on overall effect size, there was a large amount of residual heterogeneity $\left(\mathrm{Q}_{\mathrm{E}}=8137.26, \mathrm{P}<0.0001\right)$ that could be further accounted for by moderators. From this point on, all results will refer to studies conducted on leaf chewing and piercing-sucking insects under laboratory conditions because data on other insect types and under field conditions were too few to allow for robust tests of moderators (see Methods).

\section{Effect of fungal infection on insect performance}

The impact of fungal infection on insect performance was dependent on the lifestyle of the fungus (H3, Table 2): insect performance was significantly reduced on plants challenged by biotrophic pathogens and endophytes, whereas insect performance was unaffected by infection with necrotrophic pathogens (Fig. 1a). Contrary to our prediction, we detected no interaction between fungal lifestyle and insect feeding guild (H4, Table 2). However, we detected a two-way interaction between insect feeding guild and the spatial scale of the interaction between insects and fungi (H5, Table 2). In particular, fungal infection strongly reduced the performance of chewing insects at a local scale (but not at a distant scale), whereas the piercing sucking insects responded in similarly to both local and distant interactions (Fig. 1b). Finally, we did not detect a three-way interaction between fungal lifestyle, insect feeding guild and spatial scale on the response of insects to plant infection $(Q M=3.34, k=678, P=0.188)$.

This article is protected by copyright. All rights reserved. 


\section{Effect of fungal infection on preference vs. performance in chewing insects}

Generally, both preference and performance of chewing insects were reduced in challenged plants as compared to not challenged plants (Fig. 2). However, the magnitude of the insect response depended on fungus lifestyle (H6, significant Fungus lifestyle $\times$ Response type interaction, see Table 2; Fig. 2). Plant infection by biotrophic fungi reduced both insect preference and performance to a similar degree, whereas plant infection by endophytes had a stronger negative effect on insect performance than on insect preference (Fig. 2). Plant infection by necrotrophic fungi did not significantly affect either preference or performance of chewing insects (Fig. 2).

\section{Publication bias and sensitivity analyses}

Visual assessment of funnel plots confirmed a symmetrical distribution of effect sizes (Appendix S1: Fig. S2), which makes publication bias unlikely. The Rosenberg's fail safe number was 292725 , which was much greater than the critical conservative value of $5 \times k+10=5575$. This result does not prove the lack of publication bias but indicates that, if present, publication bias can safely be ignored (Rosenberg 2005). There was no temporal tendency in combined effect sizes; sequentially aggregating case studies across years only contributed to increase in the accuracy around the grand mean in the cumulative metaanalysis (Appendix S1: Fig.S3). Finally, the Pearson's coefficient of correlation between effect sizes and impact factors of journals from which they were retrieved was weakly positive $(r=0.061, P=0.043)$. Altogether, these analyses indicate that our findings were robust to selective reporting and dissemination bias.

This article is protected by copyright. All rights reserved. 
Model parameters estimated with the original dataset (i.e., with multiple outcomes taken from the same primary study) were within the range of the $95 \%$ distribution of the 1000 parameters estimated after random drawing of only one case per combination of study, system and moderator level (Appendix S1: Fig. S4). Our initial predictions were therefore robust and unlikely biased by multiple measurements on the same individuals.

\section{Discussion}

Our meta-analysis, based on several hundreds of case-studies, unequivocally demonstrates that plant infection by pathogenic and endophytic fungi, on average, reduces preference and performance of insect herbivores. Even though some primary studies reported a positive effect of fungal infection on insect preference and performance (e.g., by reducing phenolic content and increasing soluble sugar content, Cardoza et al. 2003a), the overall effect size is pervasively negative and consistent across a large set of plants, herbivores, fungi and methodological approaches. And, although most of the studies used do not necessarily reflect the whole complexity of these interactions (i.e., with plants being infected by several fungi and insects at the same time), they do imply overall strong effects of the fungi on insects. Importantly, and as discussed in detail below, we detected several sources of variation in the magnitude of plant-fungus-insect interactions providing new insights on underlying mechanisms (i.e., spatial scale of interactions, insect feeding guild and fungus lifestyle).

\section{Insect performance on fungus-challenged plants are dependent of fungus lifestyle}

Biotrophic pathogens and endophytes reduced herbivore performance more than necrotrophic pathogens did. The way endophytes exploit their resources is more similar to biotrophic pathogens as they both develop in living plant tissues (Partida-Martínez and Heil 2011, García-Guzmán and Heil 2014). Such a similarity may therefore be the likely explanation of 
their similar negative effect on insect performance. On the contrary, necrotrophic pathogens produce cell-wall degrading enzymes which may contribute to the release of plant carbohydrates. A rapid increase of soluble sugars and others plant nutrients can have a positive effect on insect performance which could explain the tendency of necrotrophic fungi to increase insect performance (Cardoza et al. 2003a, Johnson et al. 2003). For example, Johnson et al. (2003) showed a positive effect of the necrotrophic pathogen Marssonina betulae on performance of the aphid Euceraphis betulae when co-occurring in silver birch trees, which was correlated with a higher concentration of free-amino acids following the degradation of leaf mesophyll cells by fungus enzymes.

A strong negative impact of endophytes on insect performance was expected, given that some of them are considered potential biocontrol agents (Gurulingappa et al. 2010, Akello and Sikora 2012, Castillo Lopez et al. 2014, Lopez and Sword 2015). Endophytes are a very diverse group (Rodriguez et al. 2009) which are present in virtually all plants (PartidaMartinez and Heil 2011). Here we show that the proven presence in plants of some particular endophyte species may have a negative impact on insect performance. Additionally, some variability in endophyte effect may be explained by their division in two major groups: clavicipitaceous and non-clavicipitaceous endophytes (Partida-Martínez and Heil 2011), the former being known to have a negative impact on insect herbivores in some grass systems (Clay 1996, Kuldau and Bacon 2008). However, we found no evidence for a stronger negative effect of clavicipitaceous endophytes than non-clavicipitaceous endophytes on herbivores, which makes unlikely that our result is blurred by a lack of taxonomic resolution in this particular group (Appendix S4). Little is known about the effect of the whole community of endophytes on insect performance in challenged plants (Peñuelas and Terradas 2014) and we cannot exclude that some plants defined as not challenged and used as control in primary studies were actually colonized by one or several endophytic fungi. In addition, 
many fungi can act as endophytes and pathogens depending on the host plant, environment, and biotic interactions (Arnold 2007). We classified them following information provided in the primary studies we used. However, we acknowledge that taking environmental context into account in further studies will deeply improve our understanding of how fungal pathogens influence herbivorous insects on shared hosts. Moreover, plants are infected by a wide community of microorganisms that may play an important role in their extended phenotype (Partida-Martínez and Heil 2011). However, little is known about the effect of the whole microbiome on insect preferences and performances. This question will require further attention, which will surely benefit from the rapid development of new generation sequencing methods (Lindahl et al. 2013).

\section{Fungus-insect interactions are scale dependent and insect guild-specific}

The magnitude of negative effects of plant pathogens on insect herbivores varies with insect feeding guild and spatial scale of fungus-insect interactions. Performance of both chewing and piercing-sucking herbivores were more reduced when they fed on fungus challenged organs (i.e., local interaction) than when they fed on not challenged organs of challenged plants (i.e., distant interaction). However, this difference was significant only for chewing insects. When interacting locally, chewing herbivores may consume both the plant and the fungal material (Moran 1998, Rostas et al. 2003, Mondy and Corio-Costet 2004). Yet, fungi may produce mycotoxins that are toxic to insects and thus directly contribute to a reduction of insect performance (Dowd 1989, Bultman and Bell 2003). This may be mainly harmful to chewing herbivores that indiscriminately consume plant and fungus tissue, but less to piercing-sucking herbivores that only consume sap.

This article is protected by copyright. All rights reserved. 
When insects and pathogens feed on different plant organs, the insect-fungus interaction is usually presumed to be plant mediated. Plant-mediated indirect interactions may then result from the fungus reducing plant growth (e.g., Al-Naemi and Hatcher 2013) or nutritional quality to herbivores (Tinney et al. 1998). Fungal infection may also trigger systemic defense responses against both fungi and herbivores (Simon and Hilker 2003, Stout et al. 2006).

Although only few studies clearly distinguished between direct and plant mediated effects of fungi on insect herbivores (e.g., by infecting a part of the leaf and subsequently allowing the insect to only feed on the not challenged part of the same leaf, Simon and Hilker 2003), the additive contribution of direct and plant mediated effects may explain the stronger negative impact of fungal infection observed on chewing and piercing-sucking herbivores in local interactions.

\section{Guild specific response to fungus infection does not depend on fungus lifestyle}

How plants respond to multiple aggressors has been widely debated (reviewed by Thaler et al. 2012) and our results contribute to this debate. Current thinking often states that while the pathway involving salicylic acid (SA) is usually induced by and effective against biotrophic pathogens and sucking herbivores (Ali and Agrawal 2012, Thaler et al. 2012, Al-Naemi and Hatcher 2013), necrotrophic pathogens and chewing herbivores principally activate and negatively respond to the jasmonic acid (JA) pathway (Ali and Agrawal 2012, Thaler et al. 2012). Empirical evidence shows reciprocal antagonism between the SA and JA signaling pathways (reviewed by Thaler et al. 2012). If such cross-talk between these two defenserelated hormonal pathways (Stout et al. 2006) is a general pattern, then piercing-sucking herbivores should perform worse on plants challenged by biotrophic pathogens than by necrotrophic pathogens, whereas chewing herbivores should have lower performance on plants challenged by necrotrophic fungi. This hypothesis received some experimental support

This article is protected by copyright. All rights reserved. 
(Mouttet et al. 2013). For instance, Al-Naemi and Hatcher (2013) showed inhibitory effect of the necrotrophic pathogen Botrytis cinerea on individual aphid Aphis fabae performances while the biotrophic rust Uromyces viciae-fabae infection enhanced aphid performance. In addition, when both fungi where applied simultaneously to the same organ they generally cancelled out each other's effect, resulting in comparable performance of aphids on dually challenged plants and challenged, control plants. Our meta-analysis did not find support for the trade-off between JA and SA. In our study, differences in performance of chewing and piercing-sucking insects on not challenged vs. challenged plants were comparable in both direction and magnitude, irrespective of fungus lifestyle. The lack of interaction between insect feeding guild and fungus lifestyle on insect performance to pathogen infection suggests that JA or SA pleiotropic effects may not be universal (Thaler et al. 2012), that they can act together, or that mechanisms other than changes in plant defenses explain the observed differences in plant-mediated effect of fungal infections.

\section{Fungal infection differentially affects herbivore preference and performance}

There is a general agreement that insect preference should match their performance (Gripenberg et al. 2010). Consistently, we show that plant infection by fungal pathogens reduces (or has no effect on) both the preference and performance of chewing herbivores. However, the difference between herbivore preference for and performance on not challenged $v s$. challenged plants did vary with the lifestyle of fungi. Such a difference may result from different fungus lifestyles differentially affecting plant traits involved in plant selection (preference) or plant quality for herbivores (performance).

This article is protected by copyright. All rights reserved. 
While insect performance is mainly affected by a change in nutritional quality and defense of host plants (Hatcher 1995, Tack and Dicke 2013), preference is frequently affected by host selection cues, like attractive colors or odors (Schoonhoven et al. 2005, Tasin et al. 2012, Rizvi et al. 2015). In plants challenged by biotrophic fungi, the negative impact of the fungus was as strong for insect preference as for performance. However, the effect of endophyte infection was stronger for insect performance than insect preference. Plant infection by endophytes is, in contrast to biotrophic pathogens, basically symptomless (Partida-Martínez and Heil 2011) and thus the endophyte is unlikely to modify host plant visual cues for insect location. We therefore suggest that reduced insect preference may be mainly driven by endophyte mediated changes in host chemical cues (e.g., volatile emissions, Rostás et al. 2015).

Finally, we did not detect any significant effect of plant infection by necrotrophic pathogens on insect preference or performance, although there was a notable tendency for preference to be more reduced than performance. Necrotrophic fungi can change visual and chemical cues used by herbivores to locate and select their host plant (Rizvi et al. 2015) which can explain the stronger negative effect of necrotrophic pathogens on insect preference than on insect performance. Moreover, there is a greater variability of insect response to necrotrophic plant infection. This is due to the fact that several papers reported a positive effect of necrotrophic fungus infection on associated insects, which was explained by the release of soluble sugars (Cardoza et al. 2003a), amino acids (Johnson et al. 2003) or volatile compounds that could enhance insect oviposition and feeding behaviors (Cardoza et al. 2002). Alternatively, variability in the magnitude of necrotrophic pathogen effects on herbivores could result from differences in the severity of induced symptoms, which may vary with the quantity and quality of infective fungal propagules. The time lag between infection by a pathogen and the expression of symptoms by the plant may also depend on the specific plant - fungus 
interaction. In general, larger and older necrotic lesions may produce more modified plant tissues and necrotic tissue, resulting in a stronger negative impact on herbivores. However, this possibility remains poorly addressed in the literature (Jaber and Vidal 2009, Mouttet et al. 2011, Akello and Sikora 2012).

\section{Conclusion and future research directions}

Meta-analyses enable testing hypotheses that cannot be addressed in a single primary study. Here, we could unequivocally show that plant infection by fungal pathogens is generally detrimental to insect herbivores, reducing both their preference and performance.

Importantly, we unravel some biological mechanisms behind the variability among published studies. In particular, we show that the magnitude of insect negative response to plant infection by fungi varies with insect feeding guild, fungus life history traits and the spatial scale of insect-fungus interactions. However, some aspects remain unclear. We identified particular gaps in knowledge that would require more experimental studies in order to better explain and predict the outcomes of such complex, tripartite interactions. An important future avenue will be to compare the relative importance of fungi on tripartite interactions, as compared to other abiotic and biotic drivers of plant-herbivore interactions and herbivore demographics.

1. What are the molecular mechanisms at work? Only few studies (Cardoza et al. 2002, 2003a) reported solid evidence for fungus-induced change in metabolites content of plant organs. In particular, the pivotal and pleiotropic role that phytohormones play in these interactions remains unclear as most studies did not measure their levels (but see Cardoza et al. 2003a). In this respect, we believe that developments in transcriptomic analyses will pave the way for a better understanding of plant physiological responses to single and multiple biotic stresses (Lazebnik et al. 2014).

This article is protected by copyright. All rights reserved. 
2. Does timing and disease progression matter? Insect response to fungal infection was shown to vary with the time elapsed since the first fungal infection (Mouttet et al. 2013) and the phase of fungal disease. Yet, there are only few studies to date that explicitly took time, disease phase or infection severity into account (Jaber and Vidal 2009, Mouttet et al. 2011, Akello and Sikora 2012). More studies controlling the timing of interactions between herbivores and fungi are required to better understand how insect response to fungal infection varies along a time gradient.

3. How are plant-fungus-insect interactions modified by other biotic factors? Most of our current knowledge is based on highly controlled laboratory or greenhouse studies (ca $87 \%$ of our dataset). Such studies are definitely useful to isolate the effects of different treatments, but they fail to address the real complexity of interactions at play. For instance, natural enemies of herbivores may respond directly or indirectly to plant fungal infection. For example, Tack et al. (2012) showed higher parasitism rates in the leaf miner Tischeria ekebladella on mildew-infected oak leaves. Fungal infection can change attraction of insect predators and parasitoids by modifying volatile emissions (Cardoza et al. 2003b, Hare 2011) or prey resource quality (Omacini et al. 2001). Fungi can also modify host plant protection provided to insect herbivores against natural enemies by altering refuge structures such as fruits and galls (Biere et al. 2002). This needs to be further evaluated (but see Bultman et al. 2003, 2012, Härri et al. 2009, Miranda et al. 2011, Bixby-Brosi and Potter 2012, Tack and Dicke 2013).

4. How do plant-fungus-insect interactions scale up to the community level? Herbivores sharing the same host plant interact with each other, either directly or indirectly (e.g., via resource depletion) (Crawford et al. 2007, Kaplan and Denno 2007, Wielgoss et al. 2012). Plant interactions with fungi may thus indirectly affect the whole insect

This article is protected by copyright. All rights reserved. 
community structure (Tack et al. 2012), triggering changes in herbivory through competitive or facilitative processes.

5. Are tripartite interactions symmetrical? So far, most studies addressed the additive and interactive effects of herbivores and pathogens on plants (Hauser et al. 2013). The present meta-analysis expands our understanding to the effects of fungi on herbivores within the same plant (Koricheva et al. 2009). Yet, very little is known about the reciprocal effects, i.e., the plant-mediated effects of insect herbivores on fungus infection (Eyles et al. 2007, Rayamaghi et al. 2006, Rostas and Hilker, Simon and Hilker 2003, Tack and Dicke 2013) or on plant susceptibility to other pathogens such as bacteria and viruses.

In natural and agricultural ecosystems, plants have to deal with a large variability of antagonistic organisms, including pathogens and insects. A better understanding of plantfungus-insect tripartite interactions is therefore crucial to improve management and control strategies of pests and diseases in these ecosystems. While our quantitative synthesis provides new insights into plant-fungus-insect interactions, a complete understanding of tripartite interactions will require expanding the results of our meta-analysis (i) with current knowledge on additive and interactive effects of herbivores and pathogens on plants (Hauser et al. 2013) and (ii) with a review of the reciprocal effect of insect herbivores on fungi (Eyles et al. 2007, Rayamaghi et al. 2006, Rostas and Hilker, Simon and Hilker 2003, Tack and Dicke 2013) and other pathogens like bacteria and viruses. 


\section{Acknowledgements}

We thank Dr. Bitty Roy and three anonymous reviewers for constructive comments on an earlier version of the manuscript. Pilar Fernandez-Conradi was supported by a grant from INRA (Department of Forest, Grassland and Freshwater Ecology) and the French Ministry of Agriculture and Forestry.

\section{References}

Akello, J., and R. Sikora. 2012. Systemic acropedal influence of endophyte seed treatment on Acyrthosiphon pisum and Aphis fabae offspring development and reproductive fitness. Biological Control 61:215-221.

Ali, J. G., and A. A. Agrawal. 2012. Specialist versus generalist insect herbivores and plant defense. Trends in Plant Science 17:293-302.

Arnold, A. E. 2007. Understanding the diversity of foliar endophytic fungi: progress, challenges, and frontiers. Fungal Biology Reviews 21:51-66.

Biere, A., J. A. Elzinga, S. C. Honders, and J. A. Harvey. 2002. A plant pathogen reduces the enemy-free space of an insect herbivore on a shared host plant. Proceedings of the Royal Society B: Biological Sciences 269:2197-2204.

Bixby-Brosi, A. J., and D. A. Potter. 2012. Endophyte-mediated tritrophic interactions between a grass-feeding caterpillar and two parasitoid species with different life histories. Arthropod-Plant Interactions 6:27-34.

Bultman, T. L., A. Aguilera, and T. J. Sullivan. 2012. Influence of fungal isolates infecting tall fescue on multitrophic interactions. Fungal Ecology 5:372-378.

Bultman, T. L., and G. D. Bell. 2003. Interaction between fungal endophytes and environmental stressors influences plant resistance to insects. Oikos 103:182-190.

This article is protected by copyright. All rights reserved. 
Bultman, T. L., M. R. McNeill, and S. L. Goldson. 2003. Isolate-dependent impacts of fungal endophytes in a multitrophic interaction. Oikos 102:491-496.

Cardoza, Y. J., H. T. Alborn, and J. H. Tumlinson. 2002. In vivo volatile emissions from peanut plants induced by simultaneous fungal infection and insect damage. Journal of chemical ecology 28:161-174.

Cardoza, Y. J., C. G. Lait, E. A. Schmelz, J. Huang, and J. H. Tumlinson. 2003a. Fungusinduced biochemical changes in peanut plants and their effect on development of beet armyworm, Spodoptera exigua Hübner (Lepidoptera: Noctuidae) larvae.

Environmental entomology 32:220-228.

Cardoza, Y. J., P. E. A. Teal, and J. H. Tumlinson. 2003b. Effect of peanut plant fungal infection on oviposition preference by Spodoptera exigua and on host-searching behavior by Cotesia marginiventris. Environmental Entomology 32:970-976.

Castagneyrol, B., and H. Jactel. 2012. Unraveling plant-animal diversity relationships: a meta-regression analysis. Ecology 93:2115-2124.

Castillo Lopez, D., K. Zhu-Salzman, M. J. Ek-Ramos, and G. A. Sword. 2014. The entomopathogenic fungal endophytes Purpureocillium lilacinum (Formerly Paecilomyces lilacinus) and Beauveria bassiana negatively affect cotton aphid reproduction under both greenhouse and field conditions. PLoS ONE 9:e103891.

Clay, K. 1996. Interactions among fungal endophytes, grasses and herbivores. Researches on Population Ecology 38:191-201.

Crawford, K. M., G. M. Crutsinger, and N. J. Sanders. 2007. Host-plant genotypic diversity mediates the distribution of an ecosystem engineer. Ecology 88:2114-2120.

Crawford, K. M., J. M. Land, and J. A. Rudgers. 2010. Fungal endophytes of native grasses decrease insect herbivore preference and performance. Oecologia 164:431-444.

This article is protected by copyright. All rights reserved. 
Delaye, L., G. García-Guzmán, and M. Heil. 2013. Endophytes versus biotrophic and necrotrophic pathogens_-are fungal lifestyles evolutionarily stable traits? Fungal Diversity 60:125-135.

Dowd, P. F. 1989. Fusaric acid. A secondary fungal metabolite that synergizes toxicity of cooccurring host allelochemicals to the corn earworm, Heliothis zea (Lepidoptera). Journal of chemical ecology 15:249-254.

Ferreira, V., B. Castagneyrol, J. Koricheva, V. Gulis, E. Chauvet, and M. A. S. Graça. 2015. A meta-analysis of the effects of nutrient enrichment on litter decomposition in streams: Nutrient enrichment and litter decomposition. Biological Reviews 90:669688.

Fox, J., and S. Weisberg. 2011. An \{R $\}$ Companion to applied regression. Thousand Oaks $\{\mathrm{CA}\}$.

Friedli, J., and S. Bacher. 2001. Mutualistic interaction between a weevil and a rust fungus, two parasites of the weed Cirsium arvense. Oecologia 129:571-576.

Friesen, M. L., S. S. Porter, S. C. Stark, E. J. von Wettberg, J. L. Sachs, and E. MartinezRomero. 2011. Microbially mediated plant functional traits. Annual Review of Ecology, Evolution, and Systematics 42:23-46.

García-Guzmán, G., and M. Heil. 2014. Life histories of hosts and pathogens predict patterns in tropical fungal plant diseases. New Phytologist 201:1106-1120.

Gripenberg, S., P. J. Mayhew, M. Parnell, and T. Roslin. 2010. A meta-analysis of preference-performance relationships in phytophagous insects. Ecology Letters 13:383-393.

Gurulingappa, P., G. A. Sword, G. Murdoch, and P. A. McGee. 2010. Colonization of crop plants by fungal entomopathogens and their effects on two insect pests when in planta. Biological Control 55:34-41.

This article is protected by copyright. Alhrights reserved. 
Hare, J. D. 2011. Ecological role of volatiles produced by plants in response to damage by herbivorous insects. Annual Review of Entomology 56:161-180.

Härri, S. A., J. Krauss, and C. B. Müller. 2009. Extended larval development time for aphid parasitoids in the presence of plant endosymbionts. Ecological Entomology 34:20-25.

Hatcher, P. E. 1995. Three-way interactions between plant pathogenic fungi, herbivorous insects and their host plants. Biological Reviews 70:639-694.

Hatcher, P. E., N. D. Paul, P. G. Ayres, and J. B. Whittaker. 1994a. The effect of a foliar disease (rust) on the development of Gastrophysa viridula (Coleoptera: Chrysomelidae). Ecological Entomology 19:349-360.

Hatcher, P. E., N. D. Paul, P. G. Ayres, and J. B. Whittaker. 1994b. Interactions between Rumex spp., herbivores and a rust fungus: Gastrophysa viridula grazing reduces subsequent infection by Uromyces rumicis. Functional Ecology 8:265-272.

Hauser, T. P., S. Christensen, C. Heimes, and L. P. Kiaer. 2013. Combined effects of arthropod herbivores and phytopathogens on plant performance. Functional Ecology 27:623-632.

Hedges, L. V. 1981. Distribution theory for Glass's estimator of effect size and related estimators. Journal of Educational and Behavioral Statistics 6:107-128.

Jaber, L. R., and S. Vidal. 2009. Interactions between an endophytic fungus, aphids and extrafloral nectaries: do endophytes induce extrafloral-mediated defences in Vicia faba? Functional Ecology 23:707-714.

Jallow, M. F. A., D. Dugassa-Gobena, and S. Vidal. 2008. Influence of an endophytic fungus on host plant selection by a polyphagous moth via volatile spectrum changes. Arthropod-Plant Interactions 2:53-62.

This article is protected by copyright. All rights reserved. 
Jallow, M. F., D. Dugassa-Gobena, and S. Vidal. 2004. Indirect interaction between an unspecialized endophytic fungus and a polyphagous moth. Basic and Applied Ecology 5:183-191.

Johnson, S. N., A. E. Douglas, S. Woodward, and S. E. Hartley. 2003. Microbial impacts on plant-herbivore interactions: the indirect effects of a birch pathogen on a birch aphid. Oecologia 134:388-396.

Kaplan, I., and R. F. Denno. 2007. Interspecific interactions in phytophagous insects revisited: a quantitative assessment of competition theory. Ecology Letters 10:977994.

Keathley, C. P., and D. A. Potter. 2012. Arthropod abundance in tall fescue, Lolium arundinaceum, pastures containing novel "safe" endophytes: arthropod abundance in novel endophyte pastures. Journal of Applied Entomology 136:576-587.

Kluth, S., A. Kruess, and T. Tscharntke. 2001. Interactions between the rust fungus Puccinia punctiformis and ectophagous and endophagous insects on creeping thistle. Journal of Applied Ecology 38:548-556.

Kok, L. T., R. G. Abad, and A. Baudoin. 1996. Effects of Puccinia carduorum on musk thistle herbivores. Biological Control 6:123-129.

Koricheva, J., A. C. Gange, and T. Jones. 2009. Effects of mycorrhizal fungi on insect herbivores: a meta-analysis. Ecology 90:2088-2097.

Koricheva, J., J. Gurevitch, and K. Mengersen. 2013. Handbook of meta-analysis in ecology and evolution. Princeton University Press.

Kruess, A. 2002. Indirect interaction between a fungal plant pathogen and a herbivorous beetle of the weed Cirsium arvense. Oecologia 130:563-569.

Kuldau, G., and C. Bacon. 2008. Clavicipitaceous endophytes: their ability to enhance resistance of grasses to multiple stresses. Biological Control 46:57-71.

This article is protected by copyright. All rights reserved. 
Laine, A.-L. 2004. A powdery mildew infection on a shared host plant affects the dynamics of the Glanville fritillary butterfly populations. Oikos 107:329-337.

Lazebnik, J., E. Frago, M. Dicke, and J. J. A. van Loon. 2014. Phytohormone mediation of interactions between herbivores and plant pathogens. Journal of Chemical Ecology 40:730-741.

Lindahl, B. D., R. H. Nilsson, L. Tedersoo, K. Abarenkov, T. Carlsen, R. Kjøller, U. Kõljalg, T. Pennanen, S. Rosendahl, J. Stenlid, and H. Kauserud. 2013. Fungal community analysis by high-throughput sequencing of amplified markers - a user's guide. New Phytologist 199:288-299.

Lopez, D. C., and G. A. Sword. 2015. The endophytic fungal entomopathogens Beauveria bassiana and Purpureocillium lilacinum enhance the growth of cultivated cotton (Gossypium hirsutum) and negatively affect survival of the cotton bollworm (Helicoverpa zea). Biological Control 89:53-60.

Menjivar, R. D., J. A. Cabrera, J. Kranz, and R. A. Sikora. 2012. Induction of metabolite organic compounds by mutualistic endophytic fungi to reduce the greenhouse whitefly Trialeurodes vaporariorum (Westwood) infection on tomato. Plant and Soil $352: 233-241$.

Miranda, M. I., M. Omacini, and E. J. Chaneton. 2011. Environmental context of endophyte symbioses: interacting effects of water stress and insect herbivory. International Journal of Plant Sciences 172:499-508.

Mondy, N., and M.-F. Corio-Costet. 2004. Feeding insects with a phytopathogenic fungus influences their diapause and population dynamics. Ecological Entomology 29:711717.

Moran, P. J. 1998. Plant-mediated interactions between insects and a fungal plant pathogen and the role of plant chemical responses to infection. Oecologia 115:523-530.

This article is protected by copyright. All rights reserved. 
Mouttet, R., P. Bearez, C. Thomas, and N. Desneux. 2011. Phytophagous arthropods and a pathogen sharing a host plant: evidence for indirect plant-mediated interactions. PLoS ONE 6:e18840.

Mouttet, R., I. Kaplan, P. Bearez, E. Amiens-Desneux, and N. Desneux. 2013. Spatiotemporal patterns of induced resistance and susceptibility linking diverse plant parasites. Oecologia 173:1379-1386.

Murtaugh, P. A. 2002. Journal quality, effect size, and publication bias in meta-analysis. Ecology 83:1162-1166.

Al-Naemi, F., and P. E. Hatcher. 2013. Contrasting effects of necrotrophic and biotrophic plant pathogens on the aphid Aphis fabae. Entomologia Experimentalis et Applicata $148: 234-245$.

Omacini, M., E. J. Chaneton, C. M. Ghersa, and C. B. Müller. 2001. Symbiotic fungal endophytes control insect host-parasite interaction webs. Nature 409:78-81.

Partida-Martínez, L. P., and M. Heil. 2011. The microbe-free plant: fact or artifact? Frontiers in Plant Science 2.

Peñuelas, J., and J. Terradas. 2014. The foliar microbiome. Trends Plant Sci 19:278-280.

Arnold, A. E., and F. Lutzoni. 2007. Diversity and host range of foliar fungal endophytes: Are tropical leaves biodiversity hotspots? Ecology 88:541-549.

R Core Team. 2015. R: A language and environment for etatistical computing. R Foundation for Statistical Computing, Vienna, Austria.

Rizvi, S. Z. M., A. Raman, W. Wheatley, G. Cook, and H. Nicol. 2015. Influence of Botrytis cinerea (Helotiales: Sclerotiniaceae) infected leaves of Vitis vinifera (Vitales: Vitaceae) on the preference of Epiphyas postvittana (Lepidoptera: Tortricidae): Effect of B. cinerea infection on E. postvittana. Austral Entomology 54:60-70.

This article is protected by copyright. Alhrights reserved. 
Röder, G., M. Rahier, and R. E. Naisbit. 2007. Coping with an antagonist: the impact of a phytopathogenic fungus on the development and behaviour of two species of alpine leaf beetle. Oikos 116:1514-1523.

Rostás, M., M. G. Cripps, and P. Silcock. 2015. Aboveground endophyte affects root volatile emission and host plant selection of a belowground insect. Oecologia 177:487-497.

Rostas, M., and M. Hilker. 2002. Asymmetric plant-mediated cross-effects between a herbivorous insect and a phytopathogenic fungus. Agricultural and Forest Entomology 4:223-231.

Rostas, M., M. Simon, and M. Hilker. 2003. Ecological cross-effects of induced plant responses towards herbivores and phytopathogenic fungi. Basic and Applied Ecology $4: 43-62$.

Saikkonen, K., J. Ahlholm, M. Helander, M. Poteri, and J. Tuominen. 2001. Experimental testing of rust fungus-mediated herbivory resistance in Betula pendula. Forest Pathology 31:321-329.

Saikkonen, K., S. Saari, and M. Helander. 2010. Defensive mutualism between plants and endophytic fungi? Fungal Diversity 41:101-113.

Schoonhoven, L. M., J. J. A. van Loon, and M. Dicke. 2005. Insect-plant biology. 2nd ed. Oxford University Press, Oxford ; New York.

Simon, M., and M. Hilker. 2003. Herbivores and pathogens on willow: do they affect each other? Agricultural and Forest Entomology 5:275-284.

Spafford Jacob, H., T. E. Reilly, and K. L. Batchelor. 2007. The presence of Zygina sp. and Puccinia myrsiphylli reduces survival and influences oviposition of Crioceris sp. BioControl 52:113-127.

This article is protected by copyright. All rights reserved. 
Spoel, S. H., J. S. Johnson, and X. Dong. 2007. Regulation of tradeoffs between plant defenses against pathogens with different lifestyles. Proceedings of the National Academy of Sciences 104:18842-18847.

Stout, M. J., J. S. Thaler, and B. P. H. J. Thomma. 2006. Plant-mediated interactions between pathogenic microorganisms and herbivorous arthropods. Annual Review of Entomology 51:663-689.

Tack, A. J. M., and M. Dicke. 2013. Plant pathogens structure arthropod communities across multiple spatial and temporal scales. Functional Ecology 27:633-645.

Tack, A. J. M., S. Gripenberg, and T. Roslin. 2012. Cross-kingdom interactions matter: fungal-mediated interactions structure an insect community on oak: Fungus-plantinsect interactions. Ecology Letters 15:177-185.

Tasin, M., G. K. Knudsen, and I. Pertot. 2012. Smelling a diseased host: grapevine moth responses to healthy and fungus-infected grapes. Animal Behaviour 83:555-562.

Thaler, J. S., P. T. Humphrey, and N. K. Whiteman. 2012. Evolution of jasmonate and salicylate signal crosstalk. Trends in Plant Science 17:260-270.

Tinney, G. W., P. E. Hatcher, P. G. Aqres, N. D. Paul, and J. B. Whittaker. 1998. Inter- and intra- species differences in plants as hosts to Tyria jacobaeae. Entomologia Experimentalis Et Applicata 88:137-145.

Viechtbauer, W. 2010. Conducting meta-analyses in $\{\mathrm{R}\}$ with the $\{$ metafor $\}$ package. Journal of Statistical Software:1-48.

Wielgoss, A., Y. Clough, B. Fiala, A. Rumede, and T. Tscharntke. 2012. A minor pest reduces yield losses by a major pest: plant-mediated herbivore interactions in Indonesian cacao. Journal of Applied Ecology 49:465-473.

This article is protected by copyright. All rights reserved. 
Table 1. Effects of plant fungal infection on insect herbivores. For each hypothesis tested in the meta-analysis, the dataset used, main results and key references are given.

\begin{tabular}{|c|c|c|c|}
\hline & \begin{tabular}{|l} 
Hypotheses \\
\end{tabular} & Result & Key references \\
\hline \multicolumn{4}{|l|}{$\begin{array}{l}\text { Full data set } \\
k=1113(101)\end{array}$} \\
\hline $\begin{array}{l}\text { Overall response of } \\
\text { insect to plant } \\
\text { infection by fungi }\end{array}$ & $\begin{array}{l}\text { H1: Fungal infection } \\
\text { has a negative impact } \\
\text { on insect herbivores } \\
\text { associated with the } \\
\text { same host plant }\end{array}$ & $\begin{array}{l}\text { Insect preference and } \\
\text { performance are } \\
\text { negatively affected by } \\
\text { fungal infection }\end{array}$ & $\begin{array}{l}\text { (Hatcher 1995, Rostas } \\
\text { et al. 2003, Tack and } \\
\text { Dicke 2013) }\end{array}$ \\
\hline $\begin{array}{l}\text { Experimental } \\
\text { conditions }\end{array}$ & $\begin{array}{l}\text { H2: The impact of } \\
\text { fungal infection on } \\
\text { insect herbivores is } \\
\text { easier to detect and } \\
\text { quantify under } \\
\text { laboratory and } \\
\text { greenhouse conditions } \\
\text { than in the field }\end{array}$ & $\begin{array}{l}\text { There are no statistical } \\
\text { differences between } \\
\text { experimental } \\
\text { conditions (Table 2) }\end{array}$ & $\begin{array}{l}\text { (Kluth et al. 2001, } \\
\text { Stout et al. 2006, Tack } \\
\text { et al. 2012, Keathley } \\
\text { and Potter 2012) }\end{array}$ \\
\hline \multicolumn{4}{|l|}{$\begin{array}{l}\text { Laboratory and } \\
\text { greenhouse studies on } \\
\text { insect performance } \\
k=678(67)\end{array}$} \\
\hline Fungus lifestyle & $\begin{array}{l}\text { H3: The magnitude of } \\
\text { herbivore response to } \\
\text { fungal infection } \\
\text { depends on the fungus } \\
\text { lifestyle }\end{array}$ & $\begin{array}{l}\text { Biotrophic pathogens } \\
\text { and endophytes } \\
\text { negatively impacted } \\
\text { insect performance, but } \\
\text { there was no effect of } \\
\text { necrotrophic pathogens } \\
\text { (Fig. 1a) }\end{array}$ & $\begin{array}{l}\text { (Clay 1996, Al-Naemi } \\
\text { and Hatcher 2013, } \\
\text { García-Guzmán and } \\
\text { Heil 2014) }\end{array}$ \\
\hline $\begin{array}{l}\text { Cross-talk } \\
\text { hypothesis }\end{array}$ & $\begin{array}{l}\text { H4: Herbivore } \\
\text { response to fungal } \\
\text { infection is stronger for } \\
\text { chewing herbivores } \\
\text { when the plant is } \\
\text { challenged by a } \\
\text { necrotrophic fungus } \\
\text { and for sucking } \\
\text { herbivores when the } \\
\text { plant is challenged by a } \\
\text { biotrophic fungus }\end{array}$ & $\begin{array}{l}\text { No significant } \\
\text { interaction between } \\
\text { insect feeding guild } \\
\text { and fungus lifestyle on } \\
\text { herbivore performance } \\
\text { (Table 2) }\end{array}$ & $\begin{array}{l}\text { (Ali and Agrawal 2012, } \\
\text { Thaler et al. 2012, Al- } \\
\text { Naemi and Hatcher } \\
\text { 2013, Mouttet et al. } \\
\text { 2013, Lazebnik et al. } \\
\text { 2014) }\end{array}$ \\
\hline $\begin{array}{l}\text { Spatial scale of the } \\
\text { fungus-herbivore } \\
\text { interaction }\end{array}$ & $\begin{array}{l}\text { H5: The effect of } \\
\text { fungal infection is } \\
\text { larger at the local scale }\end{array}$ & $\begin{array}{l}\text { The effect of fungal } \\
\text { infection is, for } \\
\text { chewing insects, larger } \\
\text { at the local scale (Fig. } \\
\text { 1b) }\end{array}$ & $\begin{array}{l}\text { (Hatcher et al. 1994b, } \\
\text { Rostas and Hilker } \\
\text { 2002, Mouttet et al. } \\
\text { 2011, 2013) }\end{array}$ \\
\hline $\begin{array}{l}\text { Laboratory and } \\
\text { greenhouse studies for }\end{array}$ & & & \\
\hline
\end{tabular}

This article is protected by copyright. All rights reserved. 


\begin{tabular}{|c|l|l|l|}
\hline $\begin{array}{l}\text { chewing insects at the } \\
\text { local scale } \\
k=415(45)\end{array}$ & & \\
\hline $\begin{array}{l}\text { Differences } \\
\text { between insect } \\
\text { preference and } \\
\text { performance }\end{array}$ & $\begin{array}{l}\text { H6: The impact of } \\
\text { fungal infection differs } \\
\text { between preference and } \\
\text { performance }\end{array}$ & $\begin{array}{l}\text { Insect preference and } \\
\text { performance differ } \\
\text { between plants } \\
\text { challenged by different } \\
\text { fungus lifestyles (Fig. } \\
\text { 2) }\end{array}$ & $\begin{array}{l}\text { (Gripenberg et al. } \\
\text { 2010, Crawford et al. } \\
\text { 2010, Tack and Dicke } \\
\text { 2013) }\end{array}$ \\
\hline
\end{tabular}

Note: $k=$ number of case studies, followed by the number of corresponding articles in parentheses.

Table 2. Summary of model values for the different moderators tested. Given are the moderator, hypothesis tested, number of case studies $(k)$, model heterogeneity $\left(\mathrm{Q}_{\mathrm{M}}\right)$ and associated $P$ value.

\begin{tabular}{|l|c|c|c|c|}
\hline \multicolumn{1}{|c|}{ Moderators } & $\begin{array}{c}\text { Hypothesis } \\
\text { tested }\end{array}$ & \multicolumn{1}{|c|}{$\mathbf{Q}_{\mathbf{M}}$} & $\boldsymbol{k}$ & P-value \\
\hline $\begin{array}{l}\text { Experimental conditions } \\
\text { (Field vs. greenhouse/laboratory) }\end{array}$ & $\mathrm{H} 2$ & 0.34 & 1113 & 0.560 \\
\hline $\begin{array}{l}\text { Fungus lifestyle } \\
\text { (endophytes vs. necrotrophic pathogens vs. } \\
\text { biotrophic pathogens) }\end{array}$ & $\mathrm{H} 3$ & 7.04 & 678 & $\mathbf{0 . 0 3 0}$ \\
\hline $\begin{array}{l}\text { Fungus lifestyle } \times \text { Insect feeding guild } \\
\text { (endophytes vs. necrotrophic pathogens vs. } \\
\text { biotrophic pathogens) } \times \text { (chewing vs. piercing- } \\
\text { sucking herbivores) }\end{array}$ & H4 & 1.36 & 678 & 0.507 \\
\hline $\begin{array}{l}\text { Insect feeding guild } \times \text { Spatial scale } \\
\text { (chewing vs. piercing-sucking herbivores) } \times(\text { local } \\
\text { vs. distant) }\end{array}$ & H5 & 9.96 & 678 & $\mathbf{0 . 0 0 2}$ \\
\hline $\begin{array}{l}\text { Fungus lifestyle } \times \text { Response Type } \\
\text { (endophytes vs. necrotrophic pathogens vs. } \\
\text { biotrophic pathogens) } \times \text { (preference vs. } \\
\text { performance) }\end{array}$ & H6 & 34.43 & 415 & $<\mathbf{0 . 0 0 0 1}$ \\
\hline
\end{tabular}

This article is protected by copyright. All rights reserved. 
Figure 1: Response of insect performance to plant infection by fungal pathogens as a function of (a) fungus lifestyle and (b) insect feeding guild and spatial scale of interaction. Circles and error bars represent model parameter estimates and corresponding 95\% CI. $k$ is the number of case studies. The vertical dashed line centered on zero represents the null hypothesis (i.e., no difference between insect response to not challenged vs. challenged plants). Filled and empty circles represent significant and non-significant effect sizes, respectively. Different letters indicate significant differences between moderator levels.

Figure 2: Effects of fungal infection on preference and performance of chewing insects on fungus-challenged plants. Dots and error bars represent model parameter estimates and corresponding $95 \%$ CI. $k$ is the number of case studies. The vertical dashed line centered on zero represents the null hypothesis (i.e., no difference between insect response to not challenged vs. challenged plants). Filled and empty dots represent significant and nonsignificant effect sizes, respectively. Different letters indicate significant differences between moderator levels.

This article is protected by copyright. Alhrights reserved. 

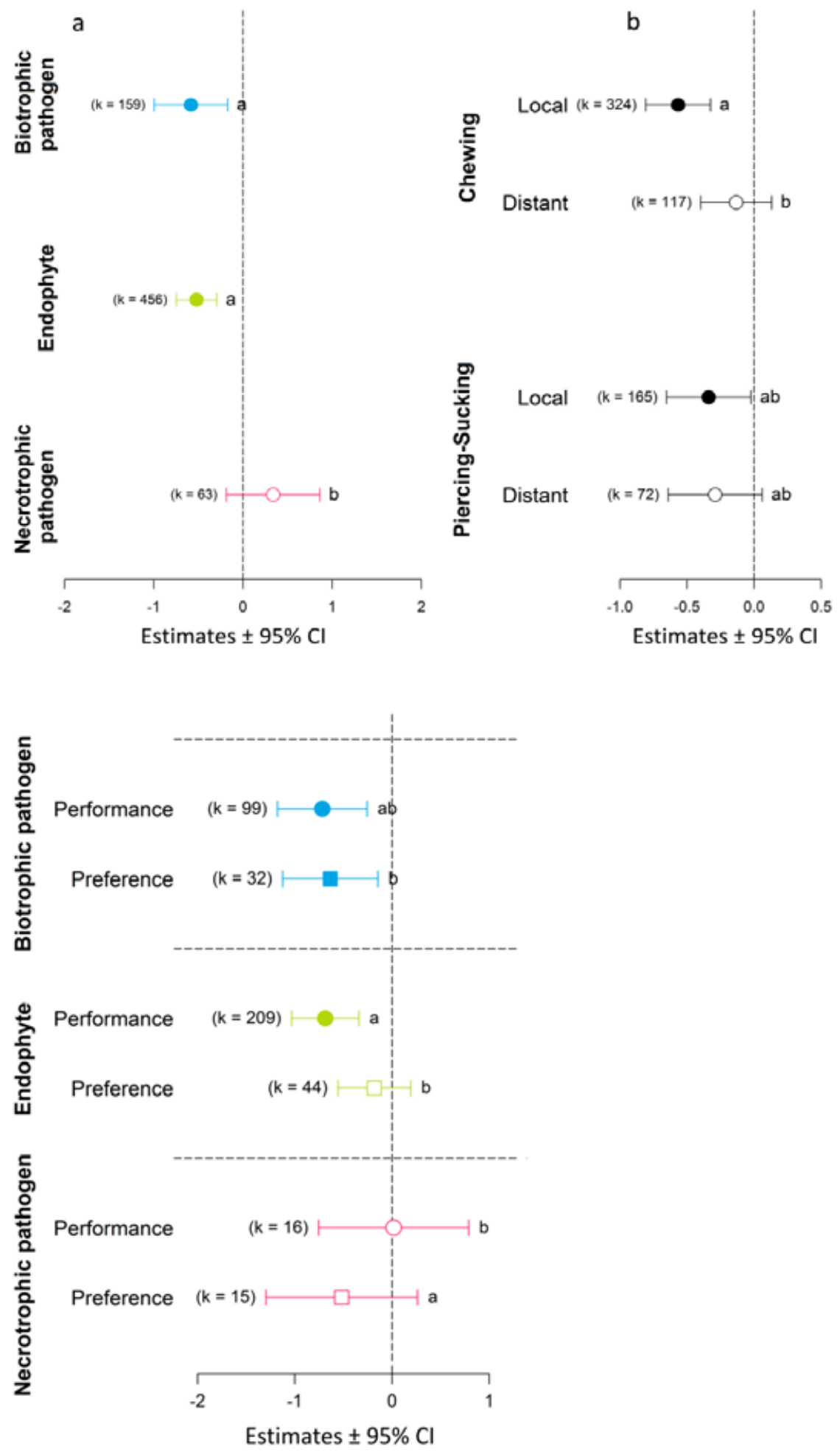

This article is protected by copyright. Alhrights reserved.

Fernandez-Conradi, P., Jactel, H., Robin, C., Tack, A. J. M., Castagneyrol, B. (2018). Fungi reduce preference and performance of insect herbivores on challenged plants. Ecology, 99 (2), 